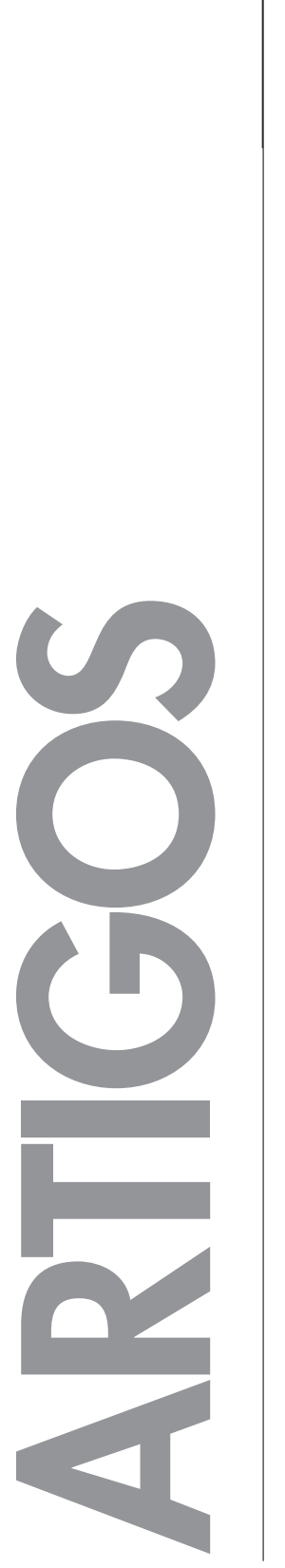


LIBERDADE DE

ENSINO VERSUS

TOTALITARISMO:

A SEMÂNTICA POLÍTICA

DOS SUBSTITUTIVOS

DE CARLOS LACERDA

DURANTE A TRAMITAÇÃO

DA LEI DE DIRETRIZES E

BASES (1958-1959)

\section{Sérgio Montalvão*}

Universidade Federal Fluminense

\section{Resumo}

Sem perder de vista os vínculos do deputado Carlos Lacerda com os interesses pecuniários das instituições particulares de ensino durante a tramitação da Lei de Diretrizes e Bases (LDB) na Câmara dos Deputados (1958-1959), o artigo destaca as relações entre a semântica dos substitutivos apresentados pelo político udenista com a cultura política católica do período, mostrando que a tese do interesse encobre uma dinâmica a ser observada nos estudos sobre a história política da educação.

\section{Palavras-chave}

Pensamento educacional católico - Lei de Diretrizes e Bases - Carlos Lacerda cultura política - semântica política.

* Professor adjunto I do Departamento de Administração da Universidade Federal Fluminense e doutor em História, Política e Bens Culturais pelo Centro de Pesquisa e Documentação em História Contemporânea do Brasil da Fundação Getúlio Vargas (CPDOC/FGV). . 
FREEDOM OF TEA-

CHING VERSUS

TOTALITARISM:

\author{
THE SEMANTIC
}

POLITICS OF CARLOS

LACERDA'S SUBSTITUTIVES IN

THE COURSE OF THE

GUIDELINES AND BASES

ACT (1958-1959)

Contact

Universidade Federal Fluminense Centro de Estudos Sociais Aplicados Rua Mário Santos Braga, $n^{\circ} 30$ - $7^{\circ}$ andar 24020-005 - Centro - Niterói E-mail: stalvao@yahoo.com.br

\section{Sérgio Montalvão}

Universidade Federal Fluminense

\begin{abstract}
Without losing sight of the links of Congressman Carlos Lacerda with the pecuniary interests of the private schools during the course of the Guidelines and Bases Act (LDB) in the parliament (1958-1959), the article highlights the connections between the semantics of the substitutives presented by this UDN (National Democratic Union Party) politician with the catholic political culture of that historical period, showing that the thesis of the interest disguises some dynamics that must be observed in the studies on the political history of education.
\end{abstract}

\title{
Keywords
}

Catholic educational thought - Guidelines and Bases Act - Carlos Lacerda - political culture - politics semantics. 
A educação escolar estava quase toda nas mãos da Igreja. Havia relativamente poucas escolas públicas. A sociedade vivia quase em regime de cristandade. Não havendo a televisão, as famílias podiam educar seus filhos nos valores cristãos dentro dos seus lares, nos colégios e comunidades paroquiais católicas. No Colégio Santo Inácio, tínhamos a missa dominical obrigatória assistida pelos alunos, com farda branca. Quase ninguém frequentava casas de campo nos finais de semana. ${ }^{1}$

Esse trecho da homilia proferida na missa comemorativa dos cinquenta anos da Associação Educacional Católica (AEC) é uma peça da memória que pode nos ajudar a escrever a história do período ao qual dedicamos este artigo. A comunidade católica brasileira se autorrepresentava, na década de 1950, como a detentora dos valores morais e espirituais da nação. A hierarquia eclesiástica, portanto, se via na missão de enfrentar os perigos e ameaças colocadas diante desse destino manifesto. Neste sentido, a educação escolar consistia no exercício continuado dos valores pregados no culto dominical, no catecismo e demais encontros paroquiais, originando elites capazes de influenciar a convivência política e ideológica, de enfrentar os efeitos perversos da modernização econômica e da secularização da cultura, em curso na metade do século XX.

A escolarização católica atingia principalmente a classe média e alta, vinculando-se a colégios de ensino secundário que ofereciam uma sólida formação humanística e preparatória ao ensino superior. A ampliação do quantitativo de escolas públicas de grau médio era vista com desconfiança pelos responsáveis destas instituições de ensino e suas associações de classe. Nos encontros e seminários patrocinados por eles, predominavam manifestações contra o perigo representado pelo monopólio estatal do ensino que, no limite, implicaria no fim da liberdade dos particulares ministrarem a educação escolar sem maiores interferências do poder público.

A liberdade de ensino mobilizou os católicos em todo o mundo. O Seminário Interamericano dedicado a este tema, realizado em Montevidéu, de 23 a 27 de setembro de 1957, a definiu como parte do direito fundamental dos homens buscarem a verdade e se expressarem livremente. As conclusões finais do encontro indicavam que o processo educativo decorre do meio familiar, entendido como "o meio natural para o exercício do direito

1 Homilia de d. Aloysio Penna na missa comemorativa dos 50 anos da Associação Educacional Católica (AEC)em 1996, apudSENRA, Álvaro Oliveira. Açãopolítica católicaeeducaçãoescolar.Curitiba:CRV,2011,p. 73. 
do homem a ser ensinado, instruído e educado". À família caberia escolher a orientação e os métodos de ensino recebidos pelos filhos na escola. O Estado democrático teria, por conseguinte, a obrigação de assegurar direitos iguais a todos em relação à educação. Para atingir as metas pregadas no seminário, as lideranças católicas defenderam que os textos constitucionais e as leis complementares deveriam garantir a liberdade de ensino e os direitos dos pais. Os orçamentos públicos, por sua vez, deveriam consignar recursos para facilitar aos cidadãos o acesso à educação e à cultura, utilizando métodos como a distribuição de bônus família e bolsas de estudo. O controle e a fiscalização desses benefícios caberiam a conselhos e comissões formadas por integrantes das associações familiares. ${ }^{2}$

\section{Cultura política católica e liberdade de ensino}

O ano de 1958 conheceu uma intensa campanha pela liberdade de ensino no Brasil que culminou no mês de novembro com a apresentação do substitutivo do deputado Carlos Lacerda ao projeto 2.222/57-A, até então a síntese das intenções parlamentares a respeito das Diretrizes e Bases da Educação. ${ }^{3}$ A historiografia indica, porém, que a motivação da campanha pode ser encontrada nos idos de 1956, na querela entre o deputado Fonseca e Silva e o diretor do Instituto Nacional de Estudos Pedagógicos (Inep), Anísio

2 Conclusões. In: SEMINÁRIO INTERAMERICANO DE LIBERDADE DE ENSINO. Montevidéu, 23 a 28 de setembro de 1957. Servir, agosto de 1958, p. 16-18.

3 Depois da "longa hibernação" provocada pelo poder de veto do deputado Gustavo Capanema (PSD/MG), que paralisou por quase uma década o andamento da LDB no Congresso Nacional, o projeto original de 1948 foi remontado dando origem ao projeto $\mathrm{n}^{\circ} 2.222$, cuja discussão na Câmara dos Deputados teve início em maio de 1957, sem qualquer empolgação dos parlamentares. No sexto dia do mês de novembro, o ministro Clóvis Salgado levou à reunião da Comissão de Educação e Cultura uma proposta de substitutivo à LDB, oriunda da comissão especial formada pelos educadores Antônio de Almeida Júnior (relator), Anísio Teixeira, Joaquim Faria de Góis Júnior, Lourenço Filho e Pedro Calmon, como forma de conciliar os diversos pontos de vista e acelerar a tramitação da lei. A mediação do Poder Executivo promoveu maior interesse no andamento das Diretrizes e Bases da Educação, tanto que, em 22 de novembro de 1957, ao destacar os projetos de maior importância e possibilidade de aprovação no próximo ano, o deputado Fernando Ferrari (PTB/RS) incluiu o da LDB. Discurso do deputado Fernando Ferrari na sessão parlamentar de 22 de novembro de 1957. Diário do Congresso Nacional, 22/11/1957. Disponível em http://imagem.camara. gov.br/dc_20b.asp. Acesso em: 19/12/2010. Em maio de 1958, surge então o substitutivo da comissão parlamentar formada por Lauro Cruz, Nestor Jost e Alfredo Palermo, conhecido pela sigla 2.222/A, em muito inspirado na ação de Clóvis Salgado, contra a qual irá dirigir-se a Igreja católica e o deputado Carlos Lacerda na campanha em defesa da liberdade de ensino. 
Teixeira, representantes da oposição entre a escola pública e a escola privada como vetores da democratização do ensino. É o que defende Ester Buffa:

Em novembro de 1956, ocorrem dois acontecimentos que marcam o início do embate, que daí para diante se radicaliza cada vez mais. No dia 5 desse mês, o padre deputado Fonseca e Silva pronuncia um primeiro discurso na Câmara Federal, atacando Anísio Teixeira, diretor do Inep, e Almeida Júnior, relator-geral do anteprojeto original (o de 1948), de se insurgirem contra os interesses das escolas confessionais. E no dia 14, pressionada por reiteradas reclamações do plenário da Câmara, a Comissão de Educação e Cultura apresenta finalmente o seu parecer. Com isso, os debates sobre o projeto passam a se desenvolver predominantemente no plenário da Câmara, o que confere às discussões em torno das diretrizes e bases da educação uma feição nitidamente política. O discurso de Fonseca e Silva teve exatamente esse mérito: obrigar os interesses conflitantes a se manifestarem num jogo político aberto. ${ }^{4}$

Pouco conhecido no cenário político nacional, o padre José Trindade da Fonseca e Silva estreou na Câmara dos Deputados em 1955, após ter sido secretário de Educação e Cultura de Goiás no governo de Pedro Ludovico Teixeira (1951-1954). No discurso de 5 novembro de 1956, o deputado goiano expôs um memorial a ser entregue ao ministro Clóvis Salgado, contendo uma "solene advertência" em relação à palestra de Anísio Teixeira no I Congresso de Educação do Estado de São Paulo, realizado cerca de dois meses antes, na cidade de Ribeirão Preto. Pelo olhar do padre e deputado, o encontro de educadores paulistas teria um efeito pernicioso ao excluir por completo a educação religiosa dos debates acerca da escola pública, alvejando assim o "patrimônio moral e espiritual da Igreja Católica no campo do ensino".5

No memorial dirigido ao ministro da Educação, após elogiar Anísio Teixeira pela operosidade com que este administrava as verbas do Fundo Nacional de Educação Primária (FNEP), Fonseca e Silva o criticou pela divulgação da filosofia pragmatista de John Dewey, considerando-a a retaguarda intelectual contra o apostolado católico. As ideias de Dewey, com o seu "naturalismo pedagógico, deformador de nossa mocidade, ainda orientada pelos sadios princípios da educação cristã" levavam, segundo o deputado, mesmo que por caminhos diversos, ao totalitarismo. ${ }^{6}$ Esse conceito era empregado para designar regimes políticos que investiam contra a liberdade de consciência, entendida

\footnotetext{
${ }_{4}$ BUFFA, Ester. Ideologias em conflito: escola pública e escola privada. São Paulo: Cortez, 1979, p. 21.

${ }^{5}$ Idem, p. 22.

${ }^{6}$ Diário do Congresso Nacional, 07/11/1956, p. 10.667. Disponível em http://imagem.camara. gov.br/dc_20b.asp. Acesso em: 20/12/2010.
} 
primordialmente como o direito da pessoa humana de praticar a crença religiosa, de orientar sua vida segundo princípios e dogmas inalteráveis. Mesmo que a Igreja católica mantivesse uma luta incessante contra o liberalismo desde a Era das Revoluções (1780-1830), sua posição política conservadora guardava um temor maior pelas experiências consideradas radicais de fundação de uma nova moral, inteiramente despida de contornos espirituais, do que pela postura agnóstica, de indiferença religiosa, encontrada na atitude laica do moderno Estado de direito. É por esse ponto de vista que se pode compreender a representação de Fonseca e Silva sobre a recepção do pensamento de Dewey no Brasil, endossando os alertas do clero nacional quanto às afinidades de seu sistema filosófico com o materialismo dialético de Marx e Engels. O deputado católico visava denunciar a relação perversa entre pragmatismo e marxismo, na qual a vontade de democratizar a educação coincidia com o ataque à obra realizada pelas instituições confessionais católicas, consideradas uma barreira a ser eliminada para que a ação estatal ocorresse sem constrangimentos.

A ofensiva de Fonseca e Silva não disfarça seu alinhamento ao anticomunismo da época. Este conhecido episódio da história política da educação, portanto, não se esgota em si próprio. Ele precisa ser visto numa escala que o considere em um conjunto maior de textos e enunciados católicos, colocando-nos em contato com a cultura política dos representantes do segmento religioso que predominava na maior parte da população brasileira. ${ }^{7}$

Em uma conjuntura de declínio parcial da Igreja da neocristandade, cujo projeto de conversão das instituições republicanas havia predominado entre 1930 e 1945, o envolvimento da religião católica com as questões sociais e po-

\footnotetext{
${ }^{7}$ O conceito de cultura política tem povoado a historiografia desde a década de 1990, momento em que a renovação da história política se dá em um diálogo contínuo com a história cultural. Esse encontro provocou a entrada da noção de "representação" no circuito das investigações sobre o político. No esforço de definir o que é cultura política, Serge Berstein testemunha essa recepção: "Os historiadores entendem por cultura política um grupo de representações, portadoras de normas e valores, que constituem a identidade das grandes famílias políticas e que vão muito além da noção reducionista de partido político". BERSTEIN, Serge. Culturas políticas e historiografia. In. AZEVEDO, Cecília, ROLLEMBERG, Denise, KNAUSS, Paulo, BICALHO, Maria Fernanda Batista e QUADRAT, Samantha Vaz. Cultura política, memória e historiografia. Rio de Janeiro: FGV, 2009, p. 31. A ênfase nos aspectos culturais possibilitou aos historiadores políticos desvencilharem-se da tradicional história das ideias políticas, valendo-se desses novos insights para ressaltar as articulações entre ideologias formalmente descritas, em livros e manifestos, e a prática comum dos militantes, sem a qual não haveria como essas ideologias penetrarem em uma parte significativa da sociedade.
} 
líticas era encarado de maneira desigual pelas principais tendências ideológicas do clero brasileiro. A divisão da hierarquia eclesiástica entre "tradicionalistas" e "modernizadores conservadores" sugerida por Scott Mainwaring, ${ }^{8}$ a despeito das opiniões divergentes acerca da reforma institucional, porém, não foi suficiente para quebrar a unidade da cultura política católica, constituída em torno de uma identidade militante, ainda na Primeira República. E isso se refere às escolhas relativas a questões que iriam demandar engajamento do grupo, aos procedimentos para enfrentá-las e aos agentes que teriam condições de melhor representar a Igreja em seus enfrentamentos políticos.

Nas edições da revista Vozes, podemos acompanhar um pouco mais de perto o trajeto da cultura política católica nos anos finais da década de 1950, dado a relevância da editora homônima que a patrocinava, envolvida numa fase de expansão de seus negócios e diversificação de suas linhas editoriais. ${ }^{9}$ Após o levantamento feito na seção de periódicos da Biblioteca Nacional, o primeiro ponto a ser ressaltado é o apelo desta publicação ao engajamento dos fiéis nas questões do tempo presente, ou seja, o ativismo católico.

A revista, que completava cinquenta anos em 1957, era, conforme nota encontrada na contracapa da sua edição do mês de janeiro, especialmente voltada para a intelectualidade da Igreja. ${ }^{10}$ Os seus editores acreditavam que este grupo social teria a missão de levar adiante o apostolado da opinião pública. Os intelectuais católicos, entendidos como indivíduos letrados, portadores de instrumentos culturais e comunicacionais suficientes para convencer o público com suas palavras e atitudes, teriam a responsabilidade de auxiliar o clero na redução dos danos causados com a perda da unidade de pensamento, após o "dilúvio generalizado da desorientação nas ideias"

\footnotetext{
${ }^{8}$ MAINWARING, Scott. A Igreja católica e a política no Brasil (1916-1985). São Paulo: Brasiliense, 1989, p. 65.

9 ANDRADES, Marcelo Ferreira de. De Petrópolis para o mundo. As estratégias editoriais dos gestores da Editora Vozes (1901-1985). Tese de doutorado em História Social, Universidade Federal do Rio de Janeiro, Rio de Janeiro, 2006, p. 198.

${ }^{10}$ Fundada pelos franciscanos da cidade de Petrópolis em 1907, a revista Vozes teve originalmente o subtítulo: "Revista mensal, religiosa, científica e literária". Dirigida nos seus primeiros dias pelo frei Pedro Sinzig, a revista afirmava no editorial de estreia que "nenhuma região da ciência e da técnica" poderia estar fora de seu programa. Sobre os anos iniciais da revista, ver: NEOTTI, frei Clarêncio. Revista Vozes: uma centenária revista de cultura. Ciberteologia: Revista de Teologia e Cultura, ano III, $\mathrm{n}^{\circ} 14$, novembro/dezembro de 2007, p. 49. Ao completar cinquenta anos, Vozes reafirmou seu interesse em subsidiar o intelectual católico, servindo como "um veículo de orientação segura através dos fatos da hora presente". Decorridos 50 anos. Vozes, ano $51, \mathrm{n}^{\circ} 1$, janeiro de 1957, p. 1.
} 
no mundo moderno. ${ }^{11}$ Com todas as agruras, acreditava Vozes, o catolicismo permanecia com um lugar bem definido no presente da humanidade. No entanto, de acordo com o papa Pio XII:

O cristão não pode ficar indiferente diante da evolução do mundo. Vendo esboçar-se, sob pressão dos acontecimentos, uma comunidade cada vez mais ligada, sabe que essa unificação, querida pelo criador, deve ter por fim a união dos espíritos e dos corações na mesma fé e no mesmo amor. ${ }^{12}$

O pontífice tratava o catolicismo como um movimento mundial que, naquele momento, enfrentava outro de iguais proporções: o materialismo ateu e suas conexões políticas com o comunismo internacional. O anticomunismo ocupou um grande espaço na revista, seja nas páginas de opinião ou nas resenhas de livros, podendo ser considerado mais um dos pilares da cultura política católica na década de $1950 .{ }^{13}$ A principal contrariedade antevista pelos colaboradores de Vozes no sistema político e social resultante da revolução russa de 1917 estava na sua visão errônea do significado do progresso para a humanidade. O artigo "Legalidade para o Partido Comunista", publicado na seção "Ideias e fatos", da edição de janeiro de 1958, ao tratar do lançamento do satélite Sputnik enquanto propaganda soviética, por exemplo, dizia:

O certo é que o Sputnik desencadeou uma onda de entusiasmo a favor da Rússia Vermelha. Predomina em nossos tempos o mito do progresso. O progresso tout court. Querem quase todos o progresso material, pouco lhes incomodando se vem ou não acompanhado do progresso moral. ${ }^{14}$

\footnotetext{
${ }^{11}$ Liberdade de pensamento. Vozes, ano $51, \mathrm{n}^{\mathrm{o}} 1$, janeiro de 1957, p. 2. O artigo faz referência à unidade de pensamento existente na cristandade medieval.

12 Alocução de Pio XII ao movimento "Pax Romana" sobre a função do intelectual católico no mundo moderno. Vozes, ano 51, n 7, julho de 1957, p. 547.

${ }^{13} \mathrm{O}$ historiador Rodrigo Patto Sá Mota afirmou que, excluindo-se os estados nacionais e suas instâncias repressivas, a Igreja católica foi a instituição que provavelmente mais se empenhou no combate ao comunismo no século XX, considerado por suas lideranças intelectuais como a consequência mais recente dos erros cometidos pelo homem durante a afirmação do mundo moderno. MOTTA, Rodrigo Patto Sá. Em guarda contra o perigo vermelho. O anticomunismo no Brasil (1917-1964). São Paulo: Perspectiva, 2002, p. 18.

${ }^{14}$ Legalidade para o partido comunista. Vozes, ano 52, $\mathrm{n}^{\circ} 1$, janeiro de 1958, p. 41.
} 
Para o articulista católico, o prestígio da ciência soviética atraía a atenção do mundo para o comunismo, ao mesmo tempo em que dissimulava os horrores da "maior nação genocida da história". ${ }^{15}$ A retórica política da revista Vozes destacava a arte da dissimulação como instrumental comunista para conquistar novos simpatizantes e partidários. ${ }^{16}$ Era o que acontecia não apenas com o aproveitamento das conquistas técnico-científicas para os fins propagandísticos de Moscou, mas também com a apropriação do discurso nacionalista pelo PCB. Aproveitando-se da boa vontade dos jovens em defender a pátria para macular essa atitude com o discurso anti-imperialista e atraí-los para a sua esfera de influência ideológica, os comunistas precisavam ser denunciados e contidos.

No imaginário do catolicismo militante haveria um plano de conquista dos corações e mentes da juventude para a órbita do Kremlin, através das aspirações nacionais. ${ }^{17}$ A missão apostólica seria evitar que a sociedade cristã brasileira - especialmente os mais fracos, crianças, jovens e mulheres - caíssem na pregação revolucionária. Em uma elogiosa resenha do livro Doutrina contra doutrina, de Plínio Salgado, o militante católico Agenor Brandão deixava visível a sua inquietude acerca da entrada insidiosa das ideias esquerdizantes no cotidiano das famílias, lamentando o despreparo delas para enfrentá-las:

É tristemente verdadeiro o que de todo esse livro se depreende: por efeito de uma formação inadequada, da qual foi retirado qualquer ensinamento doutrinário básico e

\footnotetext{
${ }^{15}$ Idem, p. 41.

${ }^{16}$ No Brasil, afirmava Vozes, a política externa da URSS pós-Stálin já alcançava seus objetivos, visto a saída de Luís Carlos Prestes da clandestinidade, que seria, em sua opinião, o primeiro movimento pela volta do PCB à legalidade. Ao responder a interrogação sobre quem estaria, de fato, combatendo o comunismo no território brasileiro, o artigo "Legalidade para o partido comunista" foi direto: "A Igreja, o Exército, e pelo menos mais estes dois partidos: o P.R.P. e o P.D.C." (Ibidem, p. 41). Fundados junto à redemocratização que pôs fim ao Estado Novo, em 1945, o Partido de Representação Popular (PRP) e o Partido Democrata Cristão (PDC), embora com muitas nuanças que os descompatibilizavam, aproximavam-se na retórica anticomunista e ultraconservadora de pelo menos dois dos seus principais representantes, que podemos considerar como exemplares da direita reacionária. Plínio Salgado (líder integralista nos anos 1930, principal ideólogo e articulador do PRP como continuador deste movimento no regime liberal da Terceira República, candidato à presidência do Brasil pela sigla em 1955) e monsenhor Alfredo de Arruda Câmara (líder católico pernambucano, deputado da Assembleia Nacional Constituinte de 1946, reeleito deputado federal pelo partido nas demais legislaturas do período democrático).

${ }^{17}$ NUNES, pe. Adalberto de Paula. O comunismo assopra (nos jovens) a fogueira do nacionalismo. Vozes, ano 51, $\mathrm{n}^{\circ} 10$, outubro de 1957, p. 791.
} 
positivo, vivemos cercados pelo comunismo sem divisar as suas manifestações e sem pensar, sequer, em nos precavermos contra suas eventuais e inevitáveis investidas. ${ }^{18}$

Os homens de negócios, agindo de modo semelhante, também não percebiam os perigos de abrir as fronteiras comerciais para o relacionamento com países do bloco socialista. Em busca apenas de vantagens materiais, o empresariado brasileiro menosprezava as consequências dessa aproximação, vista com todas as ressalvas pelos articulistas de Vozes, ao lembrarem que a Igreja católica já se manifestara em diversas oportunidades sobre a malignidade radical do comunismo. ${ }^{19}$ Pelas páginas da revista encontramos diversos alertas contra a aceleração dos afazeres cotidianos e a ansiedade na procura do lucro monetário, como manifestações típicas dos efeitos perversos da mentalidade moderna sobre a família e a organização da sociedade, que impediam enxergar a vida pelos valores éticos do cristianismo.

Em vistas disso, outro ponto a ser enfatizado na composição da cultura política católica dos anos 1950 é a condenação do mundo moderno. Esse elemento sintetiza os demais, pois o engajamento político dos intelectuais e a luta dos fiéis contra o comunismo só fazem sentido a partir desse viés restaurador. O articulista Mesquita Pimentel relembrou aos leitores da revista Vozes que a luta da Igreja contra o modernismo teve início ainda no século XIX, adentrando o século seguinte. O papa Leão XIII, em 1893, denunciava "as manobras dos racionalistas que, inspirados em uma nova ciência livre, desprezam os métodos empregados pelos pesquisadores católicos, para conhecer, explicar e esclarecer os ensinamentos das sagradas escrituras". ${ }^{20}$

Se a nova ciência livre era aquela que não encontrava limites, que investigava e punha em dúvida todos os postulados e ensinamentos cristãos sobre a criação do mundo e a origem do homem, a escola pública, nascida das revoluções burguesas e adepta do ensino laico, permitia a expansão dessas ideias. A representação dessa escola na revista, portanto, só poderia ser negativa. O depoimento de uma jovem espanhola sobre a escola pública de seu país no período republicano, publicada na edição de março de 1958,

\footnotetext{
${ }^{18}$ BRANDÃO, Agenor. Resenha do livro Doutrina contra doutrina, de Plínio Salgado. Vozes, ano 51, $\mathrm{n}^{\mathrm{0}}$ 7, julho de 1957, p. 547, p. 603.

${ }^{19}$ Ver, por exemplo, os artigos "Relações comerciais com a Rússia" e "Os capitalistas votam pela Rússia", ambos publicados em fevereiro de 1958. No primeiro texto, destacamos a seguinte passagem: "A Igreja mostra-se coerente: o comunismo é intrinsecamente mau. Há de se esperar venha transformar-se nas relações comerciais num parceiro honesto e honrado?" (p. 132).

20 PIMENTEL, Menezes. A condenação do modernismo. Vozes, ano 51, nº 8, agosto de 1957, p. 567.
} 
mostra a repressão sofrida por aqueles que acreditavam na concepção religiosa de vida:

Estou nos bancos da escola pública. A professora é uma mulher cínica. Bem poucas figuras femininas conseguem me despertar tanta e tão viva repugnância como aquela mulher monstro que, com o que havia bebido nas fontes do liberalismo do seu tempo, me envenenava a alma. Não quis eu que minha mãe me mudasse de escola, algo me dizia que todas as do governo eram iguais e do mesmo estilo.

O clima de toda a escola leiga é mau e torna-se pior em épocas de revoluções, de erros sociais que se desejam corrigir mediante leis, sem preparar moralmente os espíritos para um regime de vida sem manchas, baseado no amor de Deus e ao próximo. ${ }^{21}$

A imagem aterrorizante da escola pública trazida por meio deste depoimento destaca que, além de repugnantes, essas escolas eram todas iguais. Os católicos acreditavam que a padronização cultural imposta pelo laicismo escolar aniquilava a liberdade individual. Com a expansão inadequada do Estado sobre a educação liquidando a liberdade de ensino, a padronização seria completa e a sociedade entraria em um processo de amorfismo sem volta. Os artigos da revista Vozes expuseram essa situação como um dos maiores dilemas do século XX.

A encíclica Divini Illius Magistri, ${ }^{22}$ o mais importante documento sobre a educação cristã até a revisão provocada pelo Concílio Vaticano II (19621965), afirmava que a escola neutra ou laica, ao excluir a religião, contrariava os princípios pedagógicos tradicionais. Com base na encíclica de Pio XI, intelectuais conservadores com acesso à imprensa deflagraram uma campanha de opinião favorável à liberdade de ensino nas páginas dos grandes jornais e nas revistas em circulação nos meios católicos. Gustavo Corção foi o primeiro a tocar no tema, em 19 e 25 de janeiro e 2 de fevereiro de 1958 n'O Estado de São Paulo. ${ }^{23}$ Poucos dias depois, Anísio Teixeira iria escrever-lhe afirmando

\footnotetext{
${ }^{21}$ Depoimento de uma jovem espanhola sobre a escola pública. Vozes, ano 52, no 3, março de 1958, p. 610.

${ }^{22}$ O texto de 1929 se constituiu em um longo discurso sobre a autoridade da Igreja e da família para exercerem a educação no mundo moderno. Nele, o papa Pio XI rejeitava o modernismo pedagógico, elegendo como inimigos a serem combatidos: o naturalismo que menospreza a formação sobrenatural cristã, a filosofia educacional voltada para autonomia da criança, a limitação da autoridade do professor, a educação sexual e o método da coeducação.

${ }^{23}$ VILLALOBOS, José Eduardo Rodrigues. Diretrizes e bases da educação: ensino e liberdade. São Paulo: Editora USP/Pioneira, 1969, p. 83-84 e LIRA, Alexandre. Os descaminhos da democracia. A Lei 4024/61 (poder político, classes sociais e educação no Brasil). Dissertação de mestrado em História, Universidade Federal Fluminense, Niterói, 2000, p. 102.
} 
defender uma posição "essencialmente idêntica" a do articulista: "A educação - não só a privada como a pública - não deve ser sujeita ao Estado, mas à sociedade". ${ }^{24}$ A solução desse impasse, porém, afastava-o radicalmente do clero. Anísio Teixeira dizia-se favorável a um governo independente para a educação, conquistado pelos conselhos locais a serem formados por pais e professores. Corção, entretanto, embora fosse favorável à participação da sociedade civil na escola, na visão de educador, a entendia como a associação dos crentes do catolicismo. Nas palavras de Anísio Teixeira: “A educação pertence aos pais: muito bem. Como eles vão organizá-la? Entregando à Igreja. Ótimo. Mas há várias Igrejas... E há os que não têm Igreja... Daí a necessidade de uma escola imparcial". ${ }^{25}$

Os católicos não concebiam a existência de uma escola neutra e imparcial. Entendiam que o liberalismo, ao tornar a religião um assunto evidentemente do âmbito privado, evocava para si a responsabilidade da orientação política e ideológica da sociedade. Declarando que todo o poder emana do povo, os liberais excluíam Deus da vida pública, entendendo a ação política como ação racional, com uma ética própria. Partidários de uma democracia em que o bem comum, e não a busca da felicidade individual, fosse a razão do bom governo, os católicos entendiam a neutralidade liberal como uma forma de anular a presença da religião na formação para a cidadania.

Os postulantes da campanha pela liberdade de ensino, no entanto, afirmavam não estarem voltados para impedir por completo a atuação do poder público na abertura de escolas, mas entendiam que não era um direito do Estado atuar com tanta força na educação. Alceu Amoroso Lima explicitou a posição da Igreja em um artigo publicado no boletim da AEC, em abril de 1959:

A função educativa não está contida na natureza do Estado, justamente porque não é uma função pública e política e sim biológica, cultural e moral, e só as funções políticas pertencem ao Estado, como representante da sociedade civil. Sendo assim o direito de educar precede, no Estado, ao dever de educar. Ao passo que na família ocorre o

\footnotetext{
${ }^{24}$ Carta de Anísio Teixeira a Gustavo Corção expondo suas ideias acerca da educação religiosa. Arquivo Anísio Teixeira, CPDOC/ FGV, ATc1958.02.23. Disponível em http://docvirt.com/

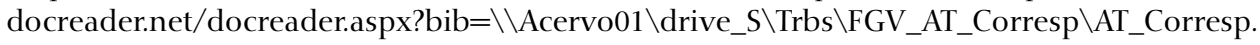
DocPro\&pasta=AT\%20c\%201958.02.23. Acesso em 10/02/2011.

${ }^{25}$ Idem.
} 
contrário. É o dever aqui que precede ao direito. Antes de ter o direito de educar, tem a família o dever de educar. ${ }^{26}$

O articulista atribuía direitos e deveres aos atores coletivos que formam a sociedade civil. A educação da prole, considerada um assunto da alçada do privado, deveria ser orientada pelos pais, que são aqueles que possuem a responsabilidade da criação. O direito de a família educar procede do dever dela pela educação dos filhos. Essa responsabilidade deveria ser inteiramente compreendida pela família cristã, conduzida e orientada pelo clero. O Estado possui o dever de organizar e proteger a sociedade, mas não é de sua natureza intervir na educação. Se o faz é pela aquisição de um direito, não pelo cumprimento de um dever. Entretanto, não conseguindo dar conta de toda a educação, as famílias têm a sua função complementada pela escola, ainda mais no que se refere à instrução. A escola é, portanto, uma instituição auxiliar da família, cumpre uma função delegada por ela, que é uma função pública, mas que não pode ser assumida inteiramente pelo público-estatal nem pela atividade meramente empresarial de transformar a educação em um serviço remunerado. É nesse espaço, entre o Estado e o mercado, que a escolarização católica colocase ideologicamente, com um papel missionário de lutar pela manutenção de uma visão de mundo que não se confundisse com a modernidade. ${ }^{27}$

\section{Salvação pelas elites}

O círculo da militância católica carioca convergia com o de muitos políticos e intelectuais da União Democrática Nacional (UDN). Do grupo católico faziam parte o advogado Sobral Pinto, o professor Alceu Amoroso Lima e o escritor/jornalista Gustavo Corção. Eles foram os responsáveis pela conversão de Carlos Lacerda, pela sua participação nas atividades do Mosteiro de São Bento e do Centro D. Vital, pelo contato que ele tivera com as ideias tomistas e neotomistas de autores como Chesterton e Maritain. Corção foi também colaborador da Tribuna da Imprensa desde a sua fundação em 1949, tendo contribuído inclusive com pedidos de empréstimo financeiro para criação do jornal. Ele atuou no conselho consultivo, responsável pelas páginas de opinião, e redigiu a coluna "Ideias e fatos" do vespertino até 1952,

\footnotetext{
${ }^{26}$ LIMA, Alceu Amoroso. O Estado e a educação. Servir, abril de 1959, p. 10.

27 SENRA, Álvaro Oliveira. Ação política católica e educação escolar, op. cit., p. 60-61.
} 
quando passou a escrever para o Diário Carioca.$^{28} \mathrm{O}$ rompimento profissional entre Corção e Lacerda, em meio a acusações de que não se dava ouvidos ao grupo católico na orientação ideológica da Tribuna, não resultou em um rompimento do jornalista e político udenista com o catolicismo, apesar de que não se possa dizer que a sua relação com a Igreja tivesse sido isenta de atritos.

A conversão de Lacerda ocorreu durante o apogeu da Guerra Fria, momento em que a luta anticomunista atingia os seus pontos máximos de histeria e tensão. Neófito no movimento católico leigo, depois de um passado esquerdista, o político udenista tornou-se um inimigo ferrenho de muitas causas que ele próprio havia defendido publicamente no jornalismo, como o divórcio. O seu conservadorismo se viu ainda mais reforçado após a viagem que fizera aos Estados Unidos, em outubro de 1948, quando conheceu o monsenhor Fulton Sheen, um arquétipo do macarthismo religioso, que o deixou impressionado com a doutrina de contenção do inimigo interno. ${ }^{29}$

A proximidade de Carlos Lacerda com os quadros da Igreja católica não se limitava aos leigos. Ele manteve uma longa relação de amizade com o arcebispo da cidade do Rio de Janeiro, d. Jayme de Barros Câmara. ${ }^{30}$ O prelado católico sucedeu o cardeal Sebastião Leme na representação do Distrito Federal, após a morte deste último em 1942, e pertencia à ala mais conservadora do clero, comprometida com o projeto restaurador da neocristandade, que reconduziu a Igreja às esferas de influência do poder nos anos de 1930, após a separação entre Estado e religião na Primeira República, recorrendo à estratégia de conversão de muitos empresários, políticos e intelectuais. A biografia de Lacerda pertence a esse movimento de recolocação do poder eclesiástico perante as instituições republicanas, sendo resumida desta forma em uma das edições da revista Vozes:

A família dos Lacerda é revolucionária. Tem a capacidade de liderar e inflamar. O avô, Sebastião Lacerda, falecido há uns quarenta anos no posto de desembargador, revolveu a política fluminense no município de Vassouras. O pai, Maurício de Lacerda, tomou parte na Revolução de Trinta, como tribuno e chefe. Carlos Lacerda, diretor da Tribuna da Imprensa, tem uma vida ligada a grandes acontecimentos da política nacional. Os

\footnotetext{
${ }^{28}$ PAULA, Cristiane Jalles de. Combatendo o bom combate: política e religião nas crônicas jornalísticas de Gustavo Corção (1953-1976). Tese de doutorado em Ciência Política, Instituto Universitário de Pesquisas do Rio de Janeiro, Rio de Janeiro, 2007, p. 62-63.

${ }^{29}$ PAIVA, Adriana Gomes de. A queda de Ícaro. Ascensão e declínio na trajetória de Carlos Lacerda. Tese de doutorado em Ciência Política, Instituto Universitário de Pesquisas do Rio de Janeiro, Rio de Janeiro, 2010, p. 163.

${ }^{30}$ BRUNEAU, Thomas. Catolicismo brasileiro em época de transição. São Paulo: Loyola, 1974, p. 131.
} 
comunistas votam-lhe ódio de morte, porque sozinho desfechou uma violenta campanha contra o candidato vermelho (sr. Iedo Fiúza) nas eleições de 1945, esmagando-o totalmente. É convertido ao catolicismo e pratica a religião, e causa assombro como no meio de sua vida agitadíssima de político e jornalista mantém as teses da doutrina cristã. ${ }^{31}$

Apesar das conquistas obtidas pelas lideranças que militavam em prol da neocristandade, os conservadores da Igreja viviam em um momento de maior fragilidade no enfrentamento com o mundo moderno ao final da década de 1950. A hierarquia católica começava a se dividir com a chegada de novas abordagens, progressistas, que enfatizavam um papel ativo da instituição para promover a mudança social. Os substitutivos defendidos por Lacerda podem ser vistos como uma tentativa de salvar as tradicionais escolas confessionais de uma conjuntura crítica, em que mais pessoas atingiam o ensino médio, mas cada vez menos eram aqueles que tinham recursos ou até mesmo vontade de estudar nelas. Por outro lado, eles representaram o apoio político do deputado ao setor mais conservador do clero nacional, com o qual ele se relacionava.

A historiografia da LDB costuma tratar a entrada de Lacerda nessa discussão, vendo-o exclusivamente como intermediário dos interesses da escola privada. ${ }^{32} \mathrm{~A}$ marca de "coveiro da escola pública" lhe foi dada por Darcy Ribeiro, ao escrever para o jornal carioca Última Hora que a defesa da liberdade de ensino das famílias restringia-se a uma fração muito limitada da sociedade - a "boa sociedade" ou as "famílias de bem" - que não quer dividir a escola com as classes populares. ${ }^{33} \mathrm{O}$ problema da tese do interesse não é o que ela expõe, mas o que deixa de dizer. Não há dúvida de que Lacerda patrocinou o interesse privatista, mas isso não encerra a questão. A pergunta

\footnotetext{
${ }^{31}$ O caso Lacerda. Vozes, ano 51, no 6, junho de 1957, p. 451.

${ }^{32}$ A historiografia da LDB sustenta que a posição de Carlos Lacerda repetiu quase inteiramente as teses do III Congresso Nacional dos Estabelecimentos Particulares de Ensino, realizado em janeiro de 1948. Este enfoque deixa pouco espaço para que se perceba que, desde o debate constituinte em 1946, encontram-se registros da posição defendida pela Igreja católica na formação do campo político-pedagógico pós-Estado Novo. No que toca ao direito das famílias sobre a educação dos filhos, o substitutivo de Lacerda foi um continuador das posições assumidas pela subcomissão VIII: "A educação é dever e direito natural dos pais, competindo supletiva e subsidiariamente aos poderes públicos". A ênfase na interseção entre a ação do parlamentar udenista e os interesses da escola particular pode ser encontrada em autores que produziram suas pesquisas com a distância de quatro décadas, demonstrando assim a vitalidade desta tese, presente nos estudos de Laerte Ramos de Carvalho (1960), José Eduardo Villalobos (1969), Demerval Saviani (1973), Luiz Antônio Cunha (1983 e 1989) e Alexandre Lira (2000). ${ }^{33}$ BOMENY, Helena. Darcy Ribeiro. Sociologia de um indisciplinado. Belo Horizonte: UFMG, 2001, p. 107.
} 
que se pode fazer é o que haveria de específico, do ponto de vista político-pedagógico, nesse discurso.

O deputado udenista se colocava publicamente como um defensor da "sociedade aberta" (democracia liberal) contra os seus inimigos (ditadores, demagogos, populistas), enfrentando-os com extrema virulência e métodos muitas vezes contraditórios, que lhe valeram a fama de "demolidor de presidentes". O liberalismo de Carlos Lacerda era francamente conservador. Estava de acordo com os bacharéis da UDN, que conduziam o partido como uma agremiação política de classe média conservadora. Os políticos udenistas ficaram conhecidos pelo discurso moralista, que incluía o combate à corrupção e a postura vigilante de zelar pelos bons costumes na vida pública. Lacerda entendia que o Brasil precisava de elites virtuosas, de boa índole moral para conduzir os destinos do país. ${ }^{34}$ Não era a escola pública, no seu ponto de vista, que iria formar essa elite, nem mesmo o eleitorado capaz de votar nela. Como assinalou Maria Victória Benevides:

O liberalismo udenista permanece, sem dúvida, marcado por um profundo elitismo. Um dos aspectos mais interessantes desse elitismo se refere à crença inabalável na presciência das elites. O corolário dessa tese se enraíza na convicção de que o povo jamais será politicamente responsável, no máximo poderá ser "politicamente educado" ou guiado ${ }^{35}$

Nada mais distante daquilo que pensavam os renovadores da educação, críticos da divisão elite/massa na sociedade democrática contemporânea. Estes intelectuais da educação, ao se aproximarem do governo JK, conquistaram novas posições no aparelho de Estado, buscando reorientá-lo no sentido da sua política sociológica. Por conta disso, o presidente Juscelino teve que enfrentar a militância católica, mobilizada em diversos momentos pela saída de Anísio Teixeira da direção do Inep. Na arena do Legislativo, políticos udenistas como Lacerda foram grandes opositores do desenvolvimentismo.

\footnotetext{
${ }^{34}$ Político emblemático da UDN, Afonso Arinos acreditava que a democracia brasileira dependia mais da qualidade dos representantes do povo do que da capacidade de escolha dos cidadãos. Ele era, portanto, um democrata com ares aristocráticos, um democrata que desconfiava da democracia quando esta era conduzida pelos aproveitadores das massas. O estudo de Fernando Lattman-Weltman sobre a sua retórica parlamentar destaca a figura do "estadista" enquanto tipo ideal de liderança política. O quase desaparecimento desses "homens-farol" era um indicativo da degenerescência das elites no mundo contemporâneo. LATTMAN-WELTMAN, Fernando. A política domesticada. Afonso Arinos e o colapso da democracia em 1964. Rio de Janeiro: FGV, 2005, especialmente o capítulo 2: De príncipes, estadistas e homens farol, ou: quando as elites degeneram, p. 34-59.

35 BENEVIDES, Maria Victória. UDN e udenismo: ambiguidades do liberalismo brasileiro. São Paulo: Paz e Terra, 1981, p. 252.
} 
Ele denunciou os riscos inflacionários da política econômica e a roubalheira que estaria por trás da construção de Brasília, meta-síntese dos "cinquenta anos em cinco". Poucos dias antes da inauguração da nova capital, o editorial da Tribuna da Imprensa era publicado com o sugestivo título de "O começo do fim e o fim do começo":

\begin{abstract}
A inauguração de Brasília marca o começo de um processo de corrupção e ruína do Brasil. O cigano que governa este país com os pés - e digo isso sem ofensa aos bons ciganos - desencadeou um processo de corrupção como não houve outro em nossa história. Nas fases mais graves do "mar de lama" havia no governo um homem que não se corrompia, embora corrompesse muita gente. Hoje não. O sr. Juscelino Kubitschek de Oliveira não é somente o grande corruptor, é também o grande corrupto. ${ }^{36}$
\end{abstract}

Lacerda descrevia Juscelino como o maior corrupto da história do Brasil, um político ainda mais destruidor que Getúlio, principalmente por estar situado à frente de um bem-sucedido projeto de poder. O combate aos excessos da máquina pública incluía os gastos com o planejamento educacional. Os renovadores, por sua vez, estiveram envolvidos de corpo a alma no projeto da Novacap, comprometendo-se com a organização do sistema escolar público de Brasília e, depois, com a criação da UnB. A experiência de planejar o futuro educacional do país, a partir da fundação de um conjunto de escolas públicas, da educação infantil ao ensino médio, enchia os olhos daqueles que acreditavam na promessa da escolarização de massas como fundamento das sociedades democráticas.

Os substitutos de Carlos Lacerda, apresentados antes da revisão feita pela Igreja em relação ao mundo moderno, ocorrida a partir do Concílio Vaticano II, foram uma reposta do conservadorismo católico (muito próximo do conservadorismo udenista) às possíveis conquistas desse tipo de planejamento estatal. Os documentos de 26 de novembro de 1958 e 15 de janeiro de 1959, muito bem recebidos pela AEC, voltavam-se ideologicamente para a proteção da família cristã, chefiada pelo homem da casa e alicerçada na propriedade privada. A instituição familiar era considerada a base permanente de uma sociedade ordeira, voltada para o trabalho e a justiça de todos. A continuidade desta "boa sociedade" dependia da educação de seus filhos, educação que não poderia se desvincular da evangelização. ${ }^{37}$

\footnotetext{
${ }^{36}$ LACERDA, Carlos. O começo do fim e o fim do começo. Tribuna da Imprensa, 18/04/1960.

37 A hegemonia social das famílias da "boa sociedade", num contexto em que se representava a casa como o lugar da liberdade, o Estado como o lugar da autoridade e a rua como o lugar
} 
Em pleno contexto da modernização econômica vivida pelo Brasil dos anos JK, esses substitutivos procuravam orientar os rumos da educação nacional evitando que a mudança social dissolvesse a posição das escolas confessionais católicas e, sobretudo, a presença da Igreja na formação para a cidadania. E isso dependia de um freio na expansão da escola pública, principalmente de nível secundário: a ameaça totalitária que iria acabar com a liberdade de ensino. Portanto, além de representar o interesse do setor privado da educação, a posição de Lacerda representava uma posição política e filosófica, muitas vezes pouco considerada, que continha um discurso sobre a democratização do ensino, alternativo ao que era defendido pelos renovadores da educação.

\section{Liberdade de ensino como legislação operante: a semântica política dos substitutivos de Carlos Lacerda}

Enquanto as autoridades católicas manifestavam descontentamento com os rumos da LDB, até novembro de 1958, o substitutivo da Comissão de Educação e Cultura esteve praticamente parado na Câmara Federal, sendo poucos os deputados que haviam se posicionado pela ida do projeto à votação em plenário. Na sessão parlamentar do dia 3, o deputado Carlos Lacerda pediu a palavra para criticar o projeto 2.222-A/57, por considerá-lo desatualizado, ainda apegado à doutrina do projeto original de 1948, mesmo depois de remontado pela comissão técnica pertinente, prometendo enviar um substitutivo próprio. ${ }^{38} \mathrm{O}$ representante udenista dissera ainda que fal-

\footnotetext{
da revolução, foi apresentada por Ilmar de Mattos para caracterizar a sociedade conservadora do Império: o tempo Saquarema. Este historiador ressalta a ideia do espaço privado enquanto garantia de liberdade, e mesmo da cidadania, na cultura política daquele tempo. A defesa da liberdade e da descentralização administrativa coincidia com os interesses dos senhorescidadãos. Ver MATTOS, Ilmar R. Tempo Saquarema. São Paulo: Hucitec, 1990, p. 133-135.

${ }^{38}$ Eleito para a Câmara Federal em novembro de 1954, pouco depois dos acontecimentos que culminaram no suicídio do presidente Vargas, o deputado udenista considerou, desde o primeiro ano de mandato, a tarefa de converter o projeto da LDB em lei a sua principal contribuição parlamentar. DULLES, John Foster. Carlos Lacerda. A vida de um lutador, volume 1: 1914-1990. Rio de Janeiro: Nova Fronteira 1992, p. 307. Em um primeiro momento, entretanto, Lacerda mostrou-se simpático ao anteprojeto da comissão Mariani, talvez para fustigar a herança estadonovista na educação e o deputado Gustavo Capanema, reeleito no mesmo pleito e reconduzido à liderança da maioria parlamentar. MONTALVÃO, Sérgio. Por uma história política da educação. A Lei de Diretrizes e Bases e a democracia da Terceira República (1946-1961). Tese de doutorado em História, Política e Bens Culturais, Centro de Pesquisa e Documentação de História Contemporânea do Brasil/Fundação Getúlio Vargas, Rio de Janeiro, 2011, p. 131-133.
} 
tava ao projeto a unidade filosófica necessária a uma lei de tal abrangência, restando-lhe uma orientação que mantinha o centralismo do Ministério da Educação e Cultura (MEC), segundo ele o principal responsável pela péssima situação da escola no quadro nacional:

A escola no Brasil tornou-se um artifício, tornou-se uma superfetação, tornou-se uma espécie de preparação para a anulação das qualidades e das vocações, das tendências e das potencialidades da inteligência do povo brasileiro, principalmente porque é organizada, é dirigida, é teleguiada, se assim me posso exprimir, por uma burocracia federal que prefixa os programas desde o Território do Rio Branco até as margens do Chuí, de tal modo que a imensa diversidade brasileira ainda não foi levada na devida conta pelo sufocante aparelho burocrático desse inútil e pernicioso Ministério da Educação e Cultura. Esse ministério, Sr. Presidente, criado pela Revolução de 1930, entre as esperanças de uma nação carente de escolas, mas carente sobretudo de um sentido a dar à educação ao seu povo, falhou, faliu, traiu as esperanças, que na sua criação o povo brasileiro depositara. Converteu-se num órgão de brutalização da consciência e da inteligência da criança brasileira. ${ }^{39}$

A "brutalização da consciência" gerada na escola exprimia-se na diferenciação dos estudantes do ensino médio, entre aqueles que cursavam o secundário e os que frequentavam o técnico-profissionalizante, priorizando o viés literário e clássico da primeira vertente. ${ }^{40} \mathrm{O}$ monopólio conferido ao MEC, quanto às diretrizes administrativas do setor, garantia a permanência desse dualismo educacional e era apresentado como a mais perniciosa consequência de uma concepção totalitária da educação:

\footnotetext{
${ }^{39}$ Discurso do deputado Carlos Lacerda na sessão parlamentar de 3 de novembro de 1958. Diário do Congresso Nacional, 04/11/1958, p. 6.457-6.458. Disponível em http://imagem.camara.gov.br/ dc_20b.asp. Acesso em: 10/12/2010. O deputado udenista criticou os projetos de 1948 e 1957 por serem contraditórios em suas orientações, o primeiro devido ao ecletismo da comissão que lhe deu origem, e o último devido às vaidades dos parlamentares e dos "mandarins" do MEC, que lutavam a todo o custo "para não deixar cair das suas mãos o controle federal da educação".

${ }^{40}$ No substitutivo de novembro de 1958, Lacerda defendia o ensino primário de oito anos (dividindo-o em duas etapas: "elementar" e "complementar"), entre outras razões, para evitar a precocidade das escolhas que surgiam com a entrada dos alunos no ensino médio, cursado na forma do secundário ou dos profissionalizantes. É curioso observar que, nesse aspecto, a demanda do deputado superava até mesmo o pleito dos "renovadores da educação" pela extensão do primário, chocando-se inclusive com o interesse das escolas católicas que lideravam o segmento posterior do ensino. Essa contradição foi revista, entretanto, no segundo substitutivo, em janeiro de 1959. VILALLOBOS, op. cit., 1969, p. 105.
} 
(...) a escola no Brasil, desde a ditadura, procurou dividir os brasileiros entre trabalhadores manuais e trabalhadores intelectuais. E ainda mais: procurou dividir brasileiros entre os que têm a vocação da técnica e os que têm a vocação da cultura.

Essa é uma concepção tipicamente aristocrática, para não dizer autocrática, para não dizer oligárquica, para não dizer reacionária, para não dizer afinal totalitária da cultura e da escola. ${ }^{41}$

O jogo de palavras feito por Lacerda lançava no mesmo "saco de gatos" conceitos díspares de educação "aristocrática", "autocrática", "oligárquica", "reacionária" e "totalitária". Entre essas palavras, no entanto, havia uma intenção depreciativa a unificá-las, lançando-as em um campo semântico contrário àquele em que se colocava o interlocutor. O vocábulo "totalitário" se destaca nesse conjunto como síntese das demais situações ("para não dizer afinal totalitária"), além de representar um temor dos dias correntes. Em um verbete da terceira edição do dicionário de Laudelino Freire, do ano de 1957, registra-se o adjetivo nas seguintes acepções:

1- Que não admite divisão. 2- Diz-se de um governo em que o grupo político centraliza todos os poderes administrativos, não permite a existência de outros partidos políticos e sobrepõe os interesses e direitos da coletividade aos do indivíduo. ${ }^{42}$

O vocábulo totalitário começou a circular em língua italiana na década de 1920, em meio à emergência do fascismo, quando o Estado nacional adquire um status inédito na estruturação da sociedade. Posteriormente, intelectuais como Giovanni Gentile, ministro da Educação de Benito Mussolini e redator do verbete La dottrina del fascismo na Enciclopédia italiana de 1932, foram responsáveis pela criação do neologismo político "totalitarismo" para designar o sentido das transformações em curso naquele país, sintetizadas na frase: "Tudo para o Estado, nada fora do Estado, nada contra o Estado".43 De expressão propagandística e doutrinária, após a Segunda Guerra Mundial, o termo ganhou projeção conceitual nas Ciências Sociais, servindo de modelo avaliativo em estudos sobre as características do poder estatal no

\footnotetext{
${ }^{41}$ Discurso do deputado Carlos Lacerda na sessão parlamentar de 3 de novembro de 1958, op. cit., p. 6.457.

${ }^{42}$ FREIRE, Laudelino. Grande e novíssimo dicionário da língua portuguesa, volume V. $3^{\mathrm{a}}$ edição. Rio de Janeiro: José Olympio, 1957.

${ }^{43}$ PAXTON, Robert. A anatomia do fascismo. São Paulo: Paz e Terra, 2007, p. 40.
} 
mundo contemporâneo, originando teorias gerais sobre o "fenômeno totalitário", como as de Carl J. Friedrich e Hannah Arendt. ${ }^{44}$

Não foi, certamente, com essa acuidade conceitual que Lacerda se apropriou dos termos "totalitário" e "totalitarismo", servindo-se deles muito mais como expressões de uma retórica política interessada em projetá-los perante o público eleitoral. Não nos deve escapar, no entanto, que, além de circular nos meios intelectuais stricto sensu, ou seja, no circuito acadêmico internacional, esse vocabulário frequentou o jornalismo político, que o utilizou de variadas formas na condenação de regimes divergentes da democracia liberal. Deve-se frisar, ainda, o uso dessas expressões em uma determinada semântica política, construída à semelhança dos "conceitos antitéticos assimétricos" de Reinhart Koselleck. ${ }^{45}$

No confronto político-ideológico acerca da democratização do ensino primário e secundário no Brasil de finais dos anos 1950, “liberdade de ensino" e "totalitarismo" foram expressões linguísticas utilizadas pelos partidários da escolarização católica para demonstrar os perigos inerentes à entrada do Estado no mercado de oportunidades escolares. Representando campos semânticos opostos, esses conceitos adjetivaram de forma desigual as ações em torno das medidas legislativas em curso. Por garantir a preservação da experiência eclesiástica e familiar na formação educacional brasileira, "liberdade de ensino" representava um bem público a ser defendido. Entrementes, "totalitarismo" enfatizava uma expectativa temerária, um futuro que se abria a partir de experiências negativas, vividas previamente em países que conheceram complexas situações de violência social. Na perspectiva aqui adotada, pode-se dizer que o conceito assumiu a forma valorativa equivalente a uma contrautopia, utilizada como estratégia de deslegitimação, de anulação do outro, com vistas a criar resistências a qualquer ação congênere ao que se considerava contrário às expectativas da política educacional católica.

\footnotetext{
${ }^{44}$ STOPPINO, Mário. Totalitarismo. In. BOBBIO, Norberto, MATTEUCCI, Nicola e PASQUINO, Gianfranco. Dicionário de política. $9^{a}$ edição. Brasília: UNB, 1997, p. 1247-1259.

${ }^{45}$ Entendem-se aqui esses pares de conceitos opostos como uma forma do interlocutor reforçar sua identidade pelo não reconhecimento do outro, nas palavras de Koselleck “(...) a história conhece numerosos conceitos que são aplicados de um modo que o reconhecimento mútuo fica excluído. Do conceito utilizado para si próprio decorre a denominação usada para o outro, que para este equivale linguisticamente a uma privação, mas que, na realidade, pode ser equiparado a uma espoliação. Trata-se, nesse caso, de conceitos opostos assimétricos. Seu oposto é contrário, porém de maneira desigual". KOSELLECK, Reinhart. Futuro passado: contribuição à semântica dos tempos históricos. Rio de Janeiro: PUC-Rio, 2006, p. 193.
} 
O argumento de Carlos Lacerda aproveitava-se da oposição entre liberdade de ensino e totalitarismo, a fim de mostrar os perigos da ingerência estatal sobre a legislação do ensino. O primeiro substitutivo do deputado, apresentado por Perilo Teixeira (UDN/CE) à relatoria da Comissão de Educação e Cultura da Câmara dos Deputados (CECCD) na reunião ordinária de 26 de novembro de 1958, ${ }^{46}$ incluía artigos que definiam a posição políticofilosófica defendida por ele, especialmente nos títulos II (Direito de educar), III (A liberdade de ensino) e IV (O Estado em relação ao ensino):

Título II, art. $2^{\circ}$ : A educação é direito inalienável e imprescindível da família.

Título III, art. $6^{\circ}$ : É vedado ao Estado exercer ou de qualquer modo favorecer o monopólio do ensino, assegurado o direito paterno de prover, com prioridade absoluta, a educação dos filhos e o dos particulares comunicarem aos outros os seus conhecimentos. Título IV, art. $10^{\circ}$ : Competem ao Estado as seguintes funções: 1) dar, quando solicitado, assistência técnica e material às escolas, a fim de lhes assegurar, em benefício da comunidade, o mais extenso e intenso rendimento de trabalho; 2) fundar e manter, em caráter supletivo, escolas oficiais, quando e onde o ensino não puder atender plenamente à população escolar. ${ }^{47}$

A orientação ideológica do documento seguia a doutrina católica dos direitos e deveres das instituições sociais face à educação, ou seja: 1) o direito da família de educar é consequência do dever que ela possui em relação ao criador, responsável maior pela vida que lhe foi atribuída para cuidar desde o nascimento até a idade adulta; 2) o Estado possui o dever de amparar as famílias e o direito de fazer funcionar escolas, onde e quando não puderem atendê-las os particulares.

Este posicionamento causou polêmica suficiente para que, mesmo no final da legislatura 1955-1959, as diretrizes e bases da educação prendessem mais a atenção dos parlamentares do que em toda a sua trajetória anterior. A sessão de 11 de dezembro foi a mais concorrida, pois nela foi apresentado o novo substitutivo da CECCD, depois de apreciada a contribuição de Carlos Lacerda e Perilo Teixeira. Sobre os acontecimentos parlamentares desta data, escreveu José Eduardo Rodrigues Villalobos:

\footnotetext{
${ }^{46}$ Carlos Lacerda não fazia parte da CECCD no momento em que o substitutivo foi enviado. Isso fez com que o udenista cearense Antônio Perilo de Sousa Teixeira ficasse encarregado de apresentar o substitutivo na referida comissão.

47 Ata da $13^{\circ}$ reunião ordinária da Comissão de Educação e Cultura da Câmara dos Deputados, 26 de novembro de 1958. Diário do Congresso Nacional, 28/11/1958, p. 7.623. Disponível em http://imagem.camara.gov.br/dc_20b.asp [acesso em 15/01/2011].
} 
Os debates nas referidas sessões foram animados desta vez, e deles participaram as mais expressivas figuras dos partidos representados naquela casa do Congresso. Travaram-se principalmente entre Carlos Lacerda, de um lado, e Nestor Jost e Lauro Cruz, de outro. Não se contentou o primeiro com o que fora aproveitado do seu substitutivo pelo novo texto da Comissão, pois nenhuma das medidas que inovara, foi o que disse em plenário, havia de fato sido nele incluída, principalmente as que visavam a "garantir a economia da educação". ${ }^{48}$

Muito diferente do marasmo que tomou conta da primeira apresentação do projeto 2.222/57 da LDB, em maio de 1957, nesse momento o assunto ganhou uma notoriedade até então desconhecida, devido principalmente à polarização provocada pelo discurso do deputado Carlos Lacerda. Defendendo o projeto da CECCD das acusações de que ainda manteria a centralização do sistema de ensino, disse Nestor Jost na tribuna da Câmara Federal:

A crítica que se tem feito intensamente nesta última semana ao substitutivo aprovado em primeira discussão é de que ele reserva excessivos poderes ao Ministério da Educação. Sr. Presidente, podemos dizer, com ufania, que é infundado o reparo. Só aqueles que não leram suficientemente o substitutivo, aqueles que não se enfronharam no que nele se contém poderão afirmar que permite a detenção nas mãos do Ministério da Educação de poderes excessivos. A comissão teve em vista a descentralização do ensino. ${ }^{49}$

Durante o encaminhamento do projeto, em resposta a Nestor Jost, mais uma vez discursou Carlos Lacerda para dizer que os objetivos da LDB deveriam garantir a descentralização e a liberdade de ensino. Ele deixava claro, afinal, a posição coincidente entre as duas partes da trama. Em favor da escola particular, afirmou:

Parece que o grande temor é que haja mais escolas no Brasil. Parece que o que apavora o Ministério é que se multipliquem as escolas, é que se retome a velha tradição brasileira pela qual o mestre-escola se improvisava na sua comuna, na sua cidade, no seu povoado, reunindo à sua volta a fome de saber das crianças e o desejo de saciá-la dos pais; criava a pequena escola particular, que ia até onde não chegou a escola pública,

\footnotetext{
${ }_{48}$ VILALLOBOS, op. cit., 1969, p. 115.

${ }^{49}$ Discurso do deputado Nestor Jost na sessão parlamentar de 11 de dezembro de 1958. Diário do Congresso Nacional, 12/12/1958, p. 8.136. Disponível em http://imagem.camara.gov.br/ dc_20b.asp. Acesso em 12/12/2010.
} 
REVISTA DE HISTÓRIA

SÃO PAULO, N 169 , p. 293-322,

JULHO / DEZEMBRO 2013
Sérgio Montalvão

Liberdade de ensino versus totalitarismo: a semântica política dos substitutivos de Carlos Lacerda durante a tramitaç̦o da Lei de Diretrizes e Bases (1958-1959)

e, em concorrência com ela, e complementando-a, começava a formar uma consciência educacional no país. ${ }^{50}$

Para o orador, o papel democratizante da ação privada era o de chegar a todos os cantos do país, até regiões não alcançadas pela escola pública, eliminando, assim, a quantidade absurda de crianças sem escola. No apelo à iniciativa particular, muito sintomaticamente, Lacerda mencionou a velha tradição brasileira do mestre-escola, deixando transparecer que a emulação necessária à melhoria da educação não seria alcançada por meio das ações racionalizadas do planejamento, mas através do personalismo e da dedicação, mesmo a partir de poucos recursos e do improviso daqueles que desejavam alcançar este objetivo.

O representante udenista convergia com as críticas feitas pelo frei Evaristo Arns na revista Vozes, ao replicar as ideias de Anísio Teixeira em Educação não é privilégio, opondo-se ao alto custo da escola pública-estatal e defendendo a importância do investimento de recursos públicos em projetos educacionais privados de expressivo alcance social, como os da Igreja católica. Entre os círculos da Escola Nova, a regra de ouro da melhoria de qualidade da educação era estender o horário escolar ao longo do dia letivo, compreendendo o turno integral de até oito horas. Para a educação primária, previa-se:

A escola primária de seis anos, em dois ciclos, o elementar de quatro anos e o complementar de dois, com seis horas mínimas de dia escolar, 240 dias letivos por ano e professores e alunos em tempo integral, isto é, proibidos os professores de acumular qualquer outra ocupação, que não fosse estritamente correlativa com o seu mister de professores primários, estes seriam os alvos a atingir, digamos, dentro de cinco anos. ${ }^{51}$

O religioso escreveu que medidas como essa teriam um efeito inverso ao esperado. Se até aquele momento, com o regime de um turno, 50\% das crianças não eram assistidas pela escola primária, o salto para o regime de seis anos de estudo, com seis ou oito horas diárias de atividades escolares, acabaria por privilegiar apenas uma minoria assistida por esse tipo de escola, geralmente encontrada nas regiões mais desenvolvidas do país, causando ainda mais desigualdade. ${ }^{52} \mathrm{O}$ efeito invertido de uma ideia aparentemente positiva nos leva ao estudo de Albert Hirschman sobre a retórica reacio-

\footnotetext{
${ }^{50}$ LACERDA, Carlos. Discursos parlamentares. Rio de Janeiro: Nova Fronteira, 1982, p. 719.

51 TEIXEIRA, Anísio. Educação não é privilégio. $5^{a}$ edição. Rio de Janeiro: UFRJ, 1994, p. 106.

52 ARNS, frei Evaristo (O.F.M.). Educação não é privilégio. Vozes, ano 51, nº 8, setembro de 1957.
} 
nária. ${ }^{53}$ Essa argumentação originou a "tese da perversidade", encontrada nas Reflexões sobre a revolução em França de Edmund Burke. Com base na teoria clássica da corrupção dos costumes políticos, que considerava a tirania como a tendência correspondente ao fracasso da democracia, Burke prognosticou que os excessos revolucionários de 1789 não fariam com que os revolucionários franceses atingissem o objetivo de suplantar a ordem tradicional, trocando-a por outra em que reinassem a liberdade e a igualdade, mas apenas levariam um pequeno grupo a controlar despoticamente o poder.

Em $A$ retórica da intransigência, Hirschman mostra que os críticos das intervenções consideradas progressistas apostam na falha de previsão dos seus oponentes, no inesperado que produz resultados opostos às intenções originais. A expansão da escola pública e laica, na aposta de frei Arns, mais do que abrir trilhas para a democratização da sociedade, mostrava-se, no limite, movida por uma vontade totalitária. Privilegiando essa escola, mas principalmente por defender uma interpretação científica da educação, Anísio Teixeira era visto como difusor de uma perspectiva anticristã do ensino, que ofendia a boa sociedade católica, não se sabe com quais intenções. É o que se depreende da leitura seguinte:

O que mais impressiona, porém, é que um homem cujas teses principais são totalitárias e cuja atividade é anticristã, se faça ouvir em todos os quadrantes do Brasil, embora convenha realçar igualmente, a bem da verdade, que dentro do próprio ministério as ideias do diretor do INEP encontram viva oposição. ${ }^{54}$

Lacerda também destacou a ação perversa do Estado nacional na educação. Ele reverberava, na tribuna da Câmara dos Deputados, os temores e representações da autoridade católica quanto ao possível risco de haver um plano para extinguir ou reduzir a um ínfimo a presença confessional da Igreja na formação dos cidadãos republicanos. O deputado procurava mostrar que a opressão burocrática da ditadura Vargas (1937-1945), ainda firme na legislação pertinente ao controle das escolas particulares, extinguia na prática a liberdade de ensino prevista na Constituição de 1946. Ele fazia coro aos pedidos de desregulamentação dos empresários do setor educacional, descontentes com a decisão da portaria n ${ }^{0} 1.509$ da Confederação Federal

\footnotetext{
${ }_{53}$ HIRSCHMAN, Albert. A retórica da intransigência: perversidade, futilidade, ameaça. São Paulo: Cia. das Letras, 1995.

${ }^{54}$ ARNS, frei Evaristo (O.F.M.). A escolha de educação não é privilégio. Vozes, ano 52, nº 6, junho de 1958, p. 461.
} 
de Abastecimento e Preços (Cofap), de 27 de dezembro de 1957, que decidiu manter para o ano de 1958 o valor das contribuições cobradas aos alunos dos estabelecimentos particulares de ensino no ano anterior. Em resposta a esta decisão do governo JK, a AEC enviou um telegrama de protesto ao presidente da República. Em alto tom de crítica, a associação afirmou que a portaria da Cofap: “(...) sem estudo prévio e consencioso da realidade nacional feriu profundamente os diretores, mestres e funcionários das escolas particulares". ${ }^{55}$

Sem desprezar a afinidade da intervenção do deputado Carlos Lacerda com os interesses mercantis do setor privado da educação, deve-se ponderar, no entanto, que não é razoável reduzi-la apenas a uma questão de defesa dos interesses financeiros das instituições particulares de ensino. Agir dessa maneira impede vislumbrar um discurso alternativo ao dos Pioneiros da educação nova, fragmentadamente amparado em uma tradição católica de pensamento educacional, que percorreu a trajetória do político fluminense, em meio ao acirrado debate político na Câmara Federal. Não por menos, o primeiro substitutivo de Lacerda foi sustado por iniciativa do próprio deputado, para que em seguida fosse acionado outro, patrocinado por ele, em janeiro de 1959.

O novo texto revisor da LDB trouxe modificações importantes em seu conteúdo normativo, mas pouco foi alterado quanto à defesa da liberdade de ensino. ${ }^{56}$ Essa continuidade demonstra, além da tentativa de assegurar maiores condições de igualdade entre as instituições públicas e privadas, inclusive na captação de recursos financeiros para estas últimas, por meio de fundos e bolsas de estudo, ${ }^{57}$ que se tratava de um ponto inegociável da proposta de diretrizes educacionais do deputado Lacerda, marcando uma posição política. Evitar que a escolarização em massa, deslanchada por um pouco confiável projeto de renovação pedagógica, ancorado no poder coercitivo do Estado, sobrepujasse a atuação de instituições formadoras de um

\footnotetext{
${ }_{55}$ A AEC condena a resolução precipitada e injusta da Cofap. Servir, abril de 1958, p. 19-23.

${ }^{56}$ José Eduardo Villalobos demonstra certa ambiguidade ao comparar o substitutivo de dezembro de 1958 e o de janeiro de 1959. Ele afirma que, no segundo substitutivo, foi dada ainda mais proteção aos interesses privatistas, mas, por outro lado, diz: "Certos dispositivos do segundo legislativo Lacerda, efetivamente, pareciam, se não anular, pelo menos atenuar as eventuais consequências do primeiro", op. cit., 1969, p. 109-110.

${ }^{57} \mathrm{O}$ artigo 70 previa que: "Além dos recursos orçamentários destinados a manter e expandir o ensino oficial, o Fundo Nacional do Ensino Primário, o do Ensino Médio e do Ensino Superior proporcionarão recursos, previamente fixados, para a cooperação financeira da União com o ensino da iniciativa privada em seus diferentes graus".
} 
público capaz de perceber a importância da família e dos valores tradicionais resume tal posição. ${ }^{58}$

\section{Considerações finais}

No contexto ideológico que caracterizou os usos do discurso político durante a tramitação da LDB na Câmara dos Deputados, o pertencimento de Lacerda à retórica excludente do totalitarismo versus liberdade de ensino, além do vínculo aos interesses pecuniários das escolas particulares que viesse a representar, torna-se um problema a ser investigado no âmbito das relações entre semântica e cultura política.

O ano de 1958 foi pródigo em uma produção textual católica que reafirmava a liberdade de ensino como fundamento das sociedades democráticas modernas do mundo ocidental, que não poderiam perder de vista a tradição cristã, identificada como origem e modo operante de seus valores morais mais profundos. Com o comunismo ateu como o grande opositor, a militância católica brasileira se desdobrou na conquista de espaços na mídia e no debate parlamentar, identificando a tímida, porém crescente, participação do Estado na educação fundamental como algo a ser sustado, em face dos efeitos perversos que uma ação aparentemente positiva poderia causar. O totalitarismo passou a frequentar o vocabulário do catolicismo militante como expressão conservadora que rejeitava a mudança social. A expansão exagerada da escola pública representava uma ameaça à liberdade de consciência das famílias, à medida que esta era facilmente transformável em es-

\footnotetext{
${ }^{58}$ Em artigo publicado a partir de pesquisas de opinião realizadas em setembro de 1960 (sobre a intenção de voto para o governo da Guanabara) e começos de 1964 (como censo aplicado aos vestibulandos do Instituto Tecnológico da Aeronáutica - ITA), o cientista político Glauco Ary Dillon Soares (1965) procurou mostrar o papel da consciência de classe entre aqueles que se diziam propensos a votar em Carlos Lacerda. A partir dos dados eleitorais que confirmaram o político udenista no governo do novo estado, Dillon Soares mostrou que a bases socioeconômicas do lacerdismo estavam nas "capas superiores" da sociedade, atraídas pelo conservadorismo do seu discurso político e moral. Com as respostas dos ingressantes no ITA, pôde o artigo reforçar a hipótese que indica a propensão ao lacerdismo não só pelos elos da situação de classe, pois essa disposição viria também do modo pelo qual os indivíduos se viam enquanto parte do conjunto social. Entre as pessoas que se identificavam com a classe "alta" ou "rica", mesmo que a origem familiar estivesse associada a "ocupações manuais não e semiespecializada", a afinidade com o lacerdismo crescia de $22 \%$ para $46 \%$. A defesa da escola particular católica mediante a defesa da liberdade de ensino pode ser vista como uma escolha adequada para reforçar o perfil de Carlos Lacerda como paladino da "boa sociedade", a qual congregava adeptos não só pela situação, mas também pela consciência de classe.
} 
cola única. Desacreditando do conceito liberal de neutralidade escolar, os católicos percebiam o campo da educação como um campo político-ideológico por excelência, nele investindo grandes doses de proselitismo e doutrinação.

Os substitutivos de Carlos Lacerda, redigidos a partir da reunião de inúmeros enunciados católicos dispersos no espaço público, tiveram o mérito de criar um instrumento formal de luta parlamentar. É nesse contexto de exposição, numa democracia que se encaminhava uma vez mais para eleger seus representantes, que o deputado udenista politizou o debate sobre a educação. O principal interesse contido nesses substitutivos esteve relacionado ao reforço de uma imagem conservadora, sedimentada na vastidão da cultura política católica, cotejada por uma semântica política específica.

\section{Referências bibliográficas}

\section{Fontes}

Arquivo Anísio Teixeira, CPDOC/FGV. Disponível em http://www.fgv.br/cpdoc/ guia/detalhesfundo.aspx?sigla=AT.

Diário da Câmara dos Deputados, 1957-1959. Disponível em http://imagem.camara. gov.br/dc 20b.asp.

Servir (Boletim da Associação Educacional Católica do Brasil), 1958-1959.

Tribuna da Imprensa, 1958-1959.

Vozes, 1957-1959.

\section{Bibliografia}

ANDRADES, Marcelo Ferreira de. De Petrópolis para o mundo. As estratégias editoriais dos gestores da Editora Vozes (1901-1985). Tese de doutorado em História Social, Universidade Federal do Rio de Janeiro, Rio de Janeiro, 2006.

BENEVIDES, Maria Victória. UDN e udenismo: ambiguidades do liberalismo brasileiro. São Paulo: Paz e Terra, 1981.

BERSTEIN, Serge. Culturas políticas e historiografia. In: AZEVEDO, Cecília, ROLLEMBERG, Denise, KNAUSS, Paulo, BICALHO, Maria Fernanda Batista e QUADRAT, Samantha Vaz. Cultura política, memória e historiografia. Rio de Janeiro: FGV, 2009, p. 29-46.

BOMENY,Helena. Darcy Ribeiro. Sociologia de um indisciplinado. Belo Horizonte: UFMG, 2001. BRUNEAU, Thomas. Catolicismo brasileiro em época de transição. São Paulo: Loyola, 1974. BUFFA, Ester. Ideologias em conflito: escola pública e escola privada. São Paulo: Cortez, 1979. CARVALHO, Laerte Ramos. As diretrizes e bases: breve história. In: BARROS, Roque Spencer Maciel de (org.). Diretrizes e bases da educação nacional. São Paulo: Pioneira, 1960, p. 203-216. 
CUNHA, Luís Antônio. A universidade crítica. O ensino superior na República populista. Rio de Janeiro: Francisco Alves, 1983.

Limites da escola particular na democratização do ensino. In. Idem (org.). Escola pública, escola particular. $3^{\mathrm{a}}$ ediç̧ão. Campinas: Autores Associados, 1989, p. 119-131.

DEWEY, John. Democracia e educação: introdução à filosofia da educação. São Paulo: Cia. Editora Nacional, 1959.

DULLES, John Foster. Carlos Lacerda. A vida de um lutador, volume 1: 1914-1990. Rio de Janeiro: Nova Fronteira, 1992.

FREIRE, Laudelino. Grande e novíssimo dicionário da língua portuguesa, volume V. $3^{\mathrm{a}}$ edição. Rio de Janeiro: José Olympio, 1957.

HIRSCHMAN, Albert. A retórica da intransigência: perversidade, futilidade, ameaça. São Paulo: Cia. das Letras, 1995.

KOSELLECK, Reinhart. Futuro passado: contribuição à semântica dos tempos históricos. Rio de Janeiro: PUC-Rio, 2006.

LACERDA, Carlos. Discursos parlamentares. Rio de Janeiro: Nova Fronteira, 1982.

LATTMAN-WELTMAN, Fernando. A política domesticada. Afonso Arinos e o colapso da democracia em 1964. Rio de Janeiro: FGV, 2005.

LIRA, Alexandre. Os descaminhos da democracia. A Lei 4.024/61 (poder político, classes sociais e educação no Brasil). Dissertação de mestrado em História, Universidade Federal Fluminense, Niterói, 2000.

MAINWARING, Scott. A Igreja católica e a política no Brasil (1916-1985). São Paulo: Brasiliense, 1989.

MATTOS, Ilmar R. Tempo Saquarema. São Paulo: Hucitec, 1990.

MONTALVÃO, Sérgio. Por uma história política da educação. A Lei de Diretrizes e Bases e a democracia da Terceira República (1946-1961). Tese de doutorado em História, Política e Bens Culturais, Centro de Pesquisa e Documentação de História Contemporânea do Brasil/Fundação Getúlio Vargas, Rio de Janeiro, 2011.

MOTTA, Rodrigo Patto Sá. Em guarda contra o perigo vermelho. O anticomunismo no Brasil (1917-1964). São Paulo: Perspectiva, 2002.

NEOTTI, frei Clarêncio. Revista Vozes: uma centenária revista de cultura. Ciberteologia: Revista de Teologia e Cultura, ano III, nº 14, novembro/dezembro de 2007, p. 48-51.

PAIVA, Adriana Gomes de. A queda de Ícaro. Ascensão e declínio na trajetória de Carlos Lacerda. Tese de doutorado em Ciência Política, Instituto Universitário de Pesquisas do Rio de Janeiro, Rio de Janeiro, 2010.

PAULA, Cristiane Jalles de. Combatendo o bom combate: política e religião nas crônicas jornalísticas de Gustavo Corção (1953-1976). Tese de doutorado em Ciência Política, Instituto Universitário de Pesquisas do Rio de Janeiro, Rio de Janeiro, 2007.

PAXTON, Robert. A anatomia do fascismo. São Paulo: Paz e Terra, 2007.

SAVIANI, Dermerval. Educação brasileira: estrutura e sistema. São Paulo: Saraiva, 1973. . Política e educação no Brasil. Campinas: Autores Associados, 2002.

SENRA, Álvaro de Oliveira. Ação política católica e educação escolar. Curitiba: CRV, 2011. 
SOARES, Gláucio Ary Dillon. As bases ideológicas do lacerdismo. Revista Civilização Brasileira. Rio de Janeiro, v. 1, n. 4, 1965, p. 49-70.

STOPPINO, Mário. Totalitarismo. In. BOBBIO, Norberto, MATTEUCCI, Nicola e PASQUINO, Gianfranco. Dicionário de política. 9ª edição. Brasília: UNB, 1997, p. 1247-1259.

TEIXEIRA, Anísio. Educação não é privilégio. 5a edição. Rio de Janeiro: UFRJ, 1994.

VILLALOBOS, José Eduardo Rodrigues. Diretrizes e bases da educação: ensino e liberdade. São Paulo: Editora USP/Pioneira, 1969.

Recebido: 20/12/2012 - Aprovado: 26/08/2013. 